\title{
THE IMPACT OF DISSENT ART IN AMERICA VERSUS THE SOCIAL MEDIA
}

\author{
Zsolt-Szilveszter SANDU \\ $\mathrm{Ph} . \mathrm{D}(\mathrm{c})$ \\ Babeș-Bolyai University Cluj-Napoca \\ sandu.szilveszter@yahoo.com
}

\section{DOI:10.24193/OJMNE.2017.24.04}

\begin{abstract}
The current study attempts to provide a comparative analysis of dissent art in America of the $20^{\text {th }}$ century and the social media of the $21^{\text {st }}$ regarding the protests which took place in the USA during the two centuries.

The results reveal the fading of some tactics used by protesters such as poetry and music and the rise of other methods such as images, videos and interactive content shared in the virtual space, putting a heavy accent on the role of social media as a communication channel for both gathering and uniting the people for a common goal.
\end{abstract}

Keywords: Dissent Art, Social Media, Protests, Protesters, USA

Art is used by people since the beginning of times in order to express their feelings and emotions. These expressions can manifest itself in paintings, sculptures, poetry and music, depending on the situation. During history, dissents of America used these channels to communicate with their target group in trying to inform them of their beliefs and to convince them to act together for a greater purpose.

This is how art became an important tool of dissent and the movements they started in the 1960s. Today riots and protests are happening more often due the many favorable conditions provided by the laws of states regarding freedom of expression and freedom of speech, but also thanks to the technologic development which had a rapid ascension since then. This is how new tools were created involuntarily which aim to contribute to the spread of information and to gather people to act. 
The connection between individuals now more than ever is thanks to the existence of the Internet and all the features provided by it. The most powerful tool existent these days are the social media networks, created to bring people from all around the word closer and to make to know each other. The after effect of these informatics systems is that people are brought together to sympathize a cause and makes whistleblowers information to break viral on the internet. Dissents of America and from all around the world are eager to use the internet in order to spread the news about their dissatisfaction related to something taking place in our times, and to change that by making people to react. Due the globalization phenomena which is intensifying day by day, shortens the time and the distances between individuals. This is why dissents need to act as fast and as convincing as possible in order to manage to spread their discontent until the problem will not become outdated and the uninformed individuals will lose their interest in it.

Brutal, romantic, passionate, direct, subtle or even hidden in the lyrics, protest music was the faithful expression of how society was set up. It showed clearly in one voice the story of the bitter injustice the people had part of and also their disregard and anger.

An intense moment in this regard happened at the civil rights movement where black cultural forms, including music, had a great contribution in mobilizing the people. Therefore, the black music tradition labeled the civil rights movement with the gospel blues, more importantly the songs of Thomas A. Dorsey as sung by Mahalia Jackson. Due the numerous television appearances and recordings, she managed to bring the gospel music into the broad American culture. As well as she inspired the people with the freedom songs to participation rate in the movement has rose considerably (Eyerman and Jamison, 1998).

Music was an indispensable element of the African-American religious culture but also for the secular sides of the southern black lives. When the boycotts began in 1954 in Baton Rouge, Louisiana, and Montgomery, Alabama, the music was already present because the church represented the main meeting place for the protestors. As the church had such a main role in these events, it was inevitable that the music genre was according to it. Furthermore, the music was giving strength, commitment and emphasized solidarity. The bridges between social classes and status groups of black people and white supporters of the cause and also between rural and urban areas, northern and southern regions were built by 
Issue no. $24 / 2017$

music. The gap between supporters and its leaders was erased and people started to see each other as equals and realized that acting in one big group in name of a cause, was more effective than following their individual goals. As the movements developed and expanded beyond the local level including wider sections of population, the music was opened up for new influences and got new functions (Eyerman and Jamison, 1998).

The civil rights movements of the sixties used stirring songs to dramatize the situation, but also to bring awareness about the mistake the leadership is doing by depriving American citizens from their fundamental rights, which should not be taken by no human being and this way inspired the masses and reached emotional knots in people's hearts which when got lighten, started the riots and protest in order to gain which was rightfully theirs. In one sentence, the humanization of the American society has begun by musical notes which inspired and gave the strength to react and stand still until the goal was reached (Malone, 1969). The following musical current which reached those behind bars was the rhythm and blues inspired songs which kept on high the morale of the inmates, facilitated the communication and created a bond between them, hoping together to see when they come out from jail, an American state ruled by equal treatment to all races and peace (Eyerman and Jamison, 1998).

Probably the most long-lasting genres of all times, characteristic even in our days to protest music was the folk and rock music. These genres were introduced with the biggest success to the popular culture and audiences seeking world peace and equal treatment to the people, by Jimi Hendrix and Janis Joplin. Others like Miles Davis, Frank Zappa, Gram Parsons and Van Morrison came up with a mixture of rock music with classical, jazz, Irish and country influences (Eyerman and Jamison, 1998).

The importance of mixing two genres had many advantages. One of them was the fact that people from different places, with different social status and different background, could easily get "connected" to others due the mixing of the musical preferences. In this way, more and more people could be convinced about the importance of fighting for a cause, but also, by the musical blend, all people could feel the lack of difference between them, feeling all just humans without the etiquette of race, religion, social status or skin color, and enjoy the harmony and peace surrounding, and binding them. Also, since the people in their thirties and 
Issue no. $24 / 2017$

above had their consecrated music genre to which they were used, but which maybe didn't had such a great influence on their children, the mixture of rock music with traditional music gave the new generation of youth a new genre of music, according to their rebelliousness and for some, who were heading in no direction, was acting as a compass to compassion, peace and freedom for which the youth always stood up to maintain and protect since then. One of the most important gathering places where artist and their fans, sharing the idea of peace, was the Woodstock Festival which had its first three-day edition in 1969. In a year, where America seemed divided and corrupted, where thousands of people were marching for the civil rights, riots were disturbing the order and soldiers were fighting in Vietnam some people just wanted peace for everyone and to bring an end to the war. Woodstock was the place where more than 400.000 young people celebrated world peace on the sound waves produced by world-known artists (Reynolds, 2009). With the risk of being called communist, antiAmerican or simply just a coward, young people who truly understood the value of human life, harmony and peace, stood up against the government and against some of the American people who saw the war justified, and spread thru the lyrics of music the ideas they believed in. Yet, the lives of those who gave their life for the country should not be forgotten, so do we need to admit that the young people protesting the war, were as brave as the fallen, and in some cases more American than those hoisting the Star-Spangled Banner in the front of their homes.

In these times was created by Phil Ochs one of the most popular protest song album called "I Ain't Marching Anymore", which can be characterized as an album of those people who instead of asking for a change, they themselves become one (Hardeep, 2015). The advantage of the protest songs beside the produced feelings was the rhythm, the chords and the catchy but direct lyrics which abled anyone with basic guitar skills to play it and even sing it. This advantage in the youth community was enormous thanks to the created bonds between groups of teenagers who joined the cause as friends and this way, not only the amount of people grew, but also their power as cause-brothers and sisters.

With the rapid technological evolution of the $21^{\text {st }}$ century, the people changed, also every action of them got an "upgrade" and here we can include also the protest and riots. 
Issue no. $24 / 2017$

The globalization phenomena shrunk the Earth and shortened the distances. Communication were no longer a question of "how?" but to "which?" channel should be used in certain circumstances. In the modern world we are living today, people make bounds within each other at music concerts which can barely go up to half a dozen, meanwhile, within the virtual environment, they can keep in touch with dozens of people, from all around the world, in the same time, without leaving their chair.

Social media networks have the most important role in maintaining these relations but also these are the channels where news can become viral in hours and influence thousands. Examples in this regard are starting with the Occupy Movement and can go further until presidential elections and the occupation of Crimea Peninsula by Russia.

In the case of the Occupy Movement art played an essential role in its creation. Here we are not talking about music but about graphical art which posted in virtual environments like Facebook and Tweeter became viral and touched people so deeply, that they felt that the time to react has come. The anonymous cultural production played a vital role in the birth of the Occupy movement by creating various photoshopped images like those featuring Lieutenant John Pike, the "Pepper Spray Cop" or the "Occupy Sesame Street" illustrations. The images created by the dissent artist were ironic, hilarious, enraged but most of all inspired awareness of the mechanism in which society is used without people's knowledge. This awareness campaign of illustrations, later was expanded in other sorts of materials like videos and documentaries, which depicted the raw reality of our times and motivated people to make a step forward and show their voice for a change (Lang and Levitsky, 2012).

This is how the movement evolved and got globalized. People from all around the world started to show their disparagement regarding certain governmental policies and acted as one to prove that those who are elected must be concerned about their electors and act in their favor not for personal gains.

The technological evolution created tools which could not be influenced and stopped by the governments of the states. The people of United States of America, showed that the 99\% has the power and made an example from this movements so every country on earth can see that the power is in the hands of the people, and it should be used when the government is no longer working in the benefit of the people, but only for a smaller circle of individuals. As 
Issue no. $24 / 2017$

the music was the biggest connection creator during the 1960s, because of the power it was able to transmit, showing the raw reality and couldn't be banned since everyone could sing the lyrics and gather to fight together for a cause, in the modern era we are living in, the place of music was taken by the internet. The virtual environment to which so many people have connection and which can be accessed today from almost any kind of electrical device from almost anywhere from the world, became a place which couldn't be controlled by the authorities. The social media networks which became a part of our everyday life starting with Facebook and Tweeter are the tools which can reach out to most of the people from the online hemisphere. Here the materials distributed can become viral in matter of hours and reach out to thousands of people regarding their interests. This is how the protest music tradition faded in front of the new technologies, but didn't lose its importance. The rush, lack of time and stress in our modern society made that people value more the time and try to spend it more effectively, so when it comes about transmitting a message, the point is to be as short, creative and to raise awareness. That is why, using images in order to raise awareness on some issue, is more effective, than sharing a protest song, which sometimes is so metaphoric than many wouldn't pay the necessary attention and the cause would not have such a fast reaction from the people. The social media networks facilitated the creation of different groups in which information about a cause was updated constantly so the supporters could know every time about the progress. Visual art has a key role in these groups to maintain the morale high, and when there is no progress in solving it, to keep the people focused on fighting and resisting, meanwhile posting creative and sarcastic images to reach out to more people and keep the protesters fate. Other type of art like poetry for example, was also a successful method to bring people to protests and motivate them. The problem in this regard hides in the group to whom the poem is addressed. The youth of our days is interested in smart, creative and direct information, like the photos with writing on them but could not pay attention for a longer poem. In this matter these kind of awareness bringing methods have to be addressed to another type of people like the academics. Teachers can use the method of protest poetry in their class, analyze it together with the students and draw conclusions. This kind of method can be very effective because of the interventions of the students and also by making them understand the problem as a whole and giving extra information which couldn't 
be told by an image shared on the social media networks. Also, these poems can have a very deep emotional impact, similar to the protest songs, and could influence people to act. But in case a student is influenced by a poem in school, it will share it's feelings, emotions and instructions to act not by a poem but with an image which can bring awareness and reach out also to those who are not interested in this form of art or simply don't have the time and interest to read it.

Art is an important part of our daily life, even if we don't observe it. We are surrounded by art at every second of a protest or in its preparation. The images on the social media networks, the protest music, and the banners at protest are all art to bring awareness to a cause. Sometimes one is used more than the other, but they are there, no matter what. We shouldn't be disappointed about the fact that there is no more protest music created in the present. The problem is that we may not hear it for the moment because the famous artists of our days have different preoccupations then singing protest songs, when the social media is full with protesting images or simply they are not interested in protesting. The protest music will always exist thanks to the "smaller" musicians who are not very known for the public and their works of art will come to surface whenever there will be a protest and a need for a song. Emotions given by protest music cannot be replaced by anything else. It has its uniqueness and power. The other types of art is also useful for transfer of knowledge and information and combined all of them, we can describe the whole process of a modern protest because it has all these elements. Whenever there will be a protest, elements of all sort of art will be present, doing their part in the benefit of the success of the cause, but there will be always songs singed at protest, no matter what, even if the protesters will have to write the lyrics on the scene, no protest will end without the people singing together.

\section{Bibliography}

1. EYERMAN, Ron and JAMISON, Andrew (1998), Music and Social Movements: Mobilizing Traditions in the Twentieth Century, New York: Cambridge University Press.

2. HARDEEP, Phull (2015), Story behind the Protest Song: A Reference Guide to the 50 Songs That Changed the 20th Century, Greenwood Publishing. 
3. MALONE, Bill C. (1969), Country Music U.S.A: a fifty-year history, University of Texas Press.

4. REYNOLDS, Susan (2009), Woodstock Revisited: 50 Far Out, Groovy, Peace-Loving, Flashback-Inducing Stories From Those Who Were There, Avon, Massachusetts: Adams Media.

5.

SCHRAGER, Amy Lang and LEVITSKY, Daniel Lang (2012),

Dreaming in Public: Building the Occupy Movement, New Internationalist. 